\title{
On Dollarization and Currency Boards: Error and Deception
}

\author{
STEVE H. HANKE* \\ Department of Economics, The Johns Hopkins University, Baltimore, MD 21218-2686, USA
}

(Received October 2002; In final form March 2003)

\begin{abstract}
A diagnosis of the laws and balance sheets of the monetary authorities in Argentina, Bosnia, Bulgaria, Estonia, Hong Kong and Lithuania is presented. With the exception of Bosnia, all employ active monetary policies and engage in sterilization. Accordingly, they are not currency boards. The methods used to dismantle the Argentine system in 2001, prior to its eventual abandonment, are presented. An evaluation of the Hong Kong system (1997-1998) suggests that its so-called currency board was not a party to counter-speculation in the stock market. Evidence is presented to show how deception was employed by the US and the IMF during the Indonesian currency board debate (1998) as a means to engineer a political regime change.
\end{abstract}

Key words: Dollarization; Currency boards; Exchange-rate regimes; Sterilization

$J E L:$ E5, E6, F3, F4, G1

\section{INTRODUCTION}

In a memoir written on the occasion of his receipt of the Nobel Prize, William Sharpe described Armen Alchian as an "eccentric theorist" who decisively excited his interest in economics. Sharpe also approvingly recounted that Alchian began his graduate course in microeconomics "by asserting that $95 \%$ of the material in economics journals was wrong or irrelevant." (Sharpe, 1995: 213)

When it comes to the burgeoning literature on "dollarization" and currency boards, Alchian's assessment is not unduly pessimistic. ${ }^{1}$ Many of those who ply these waters are superficial or honestly confused, confirming an observation made by George Stigler: "At most only a tiny set of policies have been studied with even moderate care." (Stigler, 1975: 10) If that is not bad enough, there are some who know, or should know, better but take advantage of the general confused state of affairs for political purposes, corroborating a thesis developed at length by Bauer (1976).

Much of the muddle in the literature stems from ill-defined, vague terminology. ${ }^{2}$ Indeed, the debasement of language has gone to such lengths that words - like 'currency boards' have almost lost their meaning. In large part, these semantical problems arise because economists have generally been unable or unwilling to study the internal workings of currency boards. In consequence, the basic diagnoses required to determine how currency

\footnotetext{
* Professor of Applied Economics at The Johns Hopkins University in Baltimore and a Senior Fellow at the Cato Institute in Washington, D.C. E-mail: hanke@jhu.edu
} 
boards actually work - an analysis of the laws governing these institutions and their balance sheets - are, with rare exceptions, nowhere to be found in the literature. ${ }^{3}$ Rather, much of the commentary is politically motivated and devoid of both economic analysis and references to the limited amount of sound empirical work that exists. ${ }^{4}$ In what follows, I address several of the most egregious errors and deceptions contained in the literature.

\section{CURRENCY BOARDS: PRINCIPLES AND LAWS}

During the past twenty years, laws governing the monetary authorities in Hong Kong (1983), Argentina (1991), Estonia (1992), Lithuania (1994), Bulgaria (1997) and Bosnia and Herzegovina (1997) were changed. With these changes, those monetary authorities, according to the literature, began to operate as currency boards. But is this widely accepted characterization correct? ${ }^{5}$

The answer to that question requires a specification of the rules that govern a currency board. Then, to determine how well the new systems comport with currency board principles, the laws governing the new monetary systems must be compared to the currency board rules. Finally, the new institutions' balance sheets must be examined to determine how these new systems have actually worked and whether, in practice, they adhere to currency board principles.

As a participant in the design of the new institutional arrangements (with the exception of Hong Kong ${ }^{6}$ ), I took great care to specify the features required for a monetary authority to qualify as an orthodox currency board. In all cases, I proposed such orthodoxy and produced a list of the sixteen features that distinguish currency boards from typical central banks. To avoid ambiguity, I also produced model legislation for the establishment of orthodox currency boards. (Hanke and Schuler, 1991a,b,c; Hanke, Jonung and Schuler, 1992; Hanke and Schuler, 1994; Hanke, 1996-1997)

In addition to fixed exchange rates, orthodox currency boards have six characteristic features which can be detected on the balance sheet (See Tab. I). The balance sheets of orthodox boards contain no domestic assets - or if they do, they are frozen - and, therefore, their monetary liabilities vary in a one-to-one correspondence with changes in foreign reserves. Accordingly, currency boards do not have the capacity to sterilize foreign exchange inflows or offset outflows (neutralize). Without the capacity for discretionary monetary policies, adjustments take place "automatically" via changes in the balance of payments. (Mundell, 2000: 77-78)

A review of Table I indicates that the laws governing the new monetary arrangements deviate in many important respects from currency board orthodoxy. ${ }^{7}$ Indeed, they all have the capacity to alter the net domestic assets on their balance sheets to achieve neutralization. Accordingly, they can negate the automaticity associated with orthodox currency boards. For example, all the new laws require a floor, but, with the partial exception of Bosnia and Herzegovina, have no ceiling on the foreign reserve cover for monetary liabilities. When reserves exceed the minimum requirement, the monetary authorities can freely engage in neutralization via open market operations. Neutralization can also be accomplished via changes in commercial banks' reserve requirements or impositions on the fiscal authorities and state-owned enterprises which require them to switch their deposits from (to) commercial banks to (from) the monetary authority. With the exception of Hong Kong, the new currency board laws fail to prohibit such operations.

As a matter of law, the new arrangements are not currency boards. The laws that govern them are flawed because they allow monetary and exchange rate policies to conflict with one 
TABLE I Departures From Orthodoxy in Modern Currency Board Statues.

\begin{tabular}{|c|c|c|c|c|c|c|}
\hline $\begin{array}{l}\text { Features of orthodox } \\
\text { currency boards }{ }^{i}\end{array}$ & $A R G$ & $B O S$ & $B U L$ & EST & $H K^{i i}$ & $L I T$ \\
\hline Supplies notes and coins only & $\mathrm{No}^{\mathrm{iii}}$ & $\mathrm{No}^{\text {iv }}$ & $\mathrm{No}^{\mathrm{v}}$ & $\mathrm{No}^{\mathrm{vi}}$ & $(\mathrm{No})^{\mathrm{vii}}$ & $\mathrm{No}^{\text {viii }}$ \\
\hline Full convertibility & Yes & Yes & Yes & Yes $^{\mathrm{ix}}$ & Yes & Yes $^{x}$ \\
\hline Not a lender of last resort & $\mathrm{No}^{\mathrm{xi}}$ & Yes & Yes $^{\mathrm{xii}}$ & $\mathrm{No}^{\mathrm{xiii}}$ & $(\text { Yes })^{\text {xiv }}$ & $\mathrm{No}^{\mathrm{xv}}$ \\
\hline Does not regulate commercial banks & $\mathrm{No}^{\mathrm{xvi}}$ & $\mathrm{No}^{\mathrm{xvii}}$ & Yes $^{\mathrm{xviii}}$ & $\mathrm{No}^{\mathrm{xix}}$ & $\mathrm{No}^{\mathrm{xx}}$ & $\mathrm{No}^{\mathrm{xxi}}$ \\
\hline $\begin{array}{l}\text { Cannot finance spending by } \\
\text { domestic government }\end{array}$ & $\mathrm{No}^{\mathrm{xxii}}$ & Yes & Yes & Yes & (Yes) & $\mathrm{No}^{\mathrm{xxii}}$ \\
\hline Foreign reserves of $100-115$ percent & $\mathrm{No}^{\mathrm{xxiv}}$ & $\operatorname{Yes}^{\mathrm{xxv}}$ & $\mathrm{No}^{\mathrm{xxvi}}$ & $\mathrm{No}^{\mathrm{xxvii}}$ & $\mathrm{No}^{\mathrm{xxviii}}$ & $\mathrm{No}^{\mathrm{xxix}}$ \\
\hline
\end{tabular}

Note: An entry of 'Yes' indicates that the condition is met and 'No' means the condition is not met.

${ }^{\mathrm{i}}$ The list of orthodox currency board features is based on Hanke, Jonung and Schuler (1993: 6).

${ }^{i i}$ Hong Kong is not committed to any particular monetary system, anchor currency, or exchange rate by the Basic Law or by statute law. As such, the currency board lacks a firm legal foundation (Schuler, 1999: 6). Entries in parentheses indicate what has been the practice, where no position is explicit in either the Basic Law or statute law.

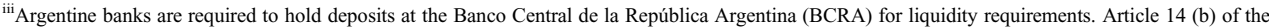
BCRA charter empowers the Executive Board to set reserve requirements, within the limits set by Article 28 .

${ }^{\text {iv }}$ Article 2, Section $3(\mathrm{~g})$ of the Law on the Central Bank of Bosnia and Herzegovina requires the CBBH to receive deposits from commercial banks to meet reserve requirements.

${ }^{v}$ Article 28, Section 2 of the Law on the Bulgarian National Bank includes deposits in the monetary liabilities of the Issue Department (the currency board). ${ }^{\mathrm{vi}}$ Estonian banks are required to hold deposits at the Central Bank of the Republic of Estonia for reserve requirements by Article 14, Section 4 of the Law on the Central Bank of the Republic of Estonia.

${ }^{\text {vii }}$ The Hong Kong Monetary Authority (HKMA) does not supply notes and coins directly. Rather, it issues Certificates of Indebtedness against which three commercial banks in Hong Kong issue notes and coins. The system, therefore, operates on a rather peculiar cash arbitrage basis. (Culp and Hanke, 1993) See Section 4 of the Exchange Fund Ordinance. The HKMA also issues Exchange Fund Bills and Exchange Fund Notes which are short-term interestbearing certificates bought and sold by commercial banks and the HKMA to manage liquidity.

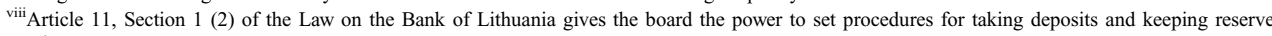
requirements.

${ }^{\mathrm{ix}}$ There is nothing in the Law on the Central Bank of the Republic of Estonia that requires full convertibility or a fixed exchange rate. Clause 3 of the Law of the Republic of Estonia on the Security for Estonian Kroon guarantees "the free exchange of Estonian kroon to convertible foreign currencies."

${ }^{\mathrm{x}}$ The is nothing in the Law on the Bank of Lithuania that requires full convertibility or a fixed exchange rate. Article 4 of the Law on the Credibility of the Litas gurantees full convertibility, however.

${ }^{\mathrm{xi}}$ Article 17, sections b and $\mathrm{c}$ of the BCRA's charter grant the BCRA the power to "grant rediscounts to financial entities on account of temporary illiquidity," "advance funds to the accounts of financial entities due to temporary illiquidity," and to enlarge the limits on such credits "under general and extraordinary circumstances" at the discretion of the management. The BCRA also maintained a Contingent Repo Facility which was meant to be triggered in the event of a systemic banking crisis, although details on the Facility were not widely available.

${ }^{x i i}$ Lender of last resort functions are delegated to the Banking Department of the Bulgarian National Bank in Article 20, section 2 of the Law on the Bulgarian National Bank

xiii Article 14, section 5 of the Law on the Central Bank of the Republic of Estonia allows the Bank to grant loans to credit institutions.

${ }^{\text {xiv }}$ The HKMA has a discount window which is separate from the Currency Board. However, see footnote 20 below for the sweeping powers that may potentially be given to the HKMA.

${ }^{x v}$ Article 11, section 1 (2) of the Law on the Bank of Lithuania gives the board the power to set procedures for rediscounts and loans to credit institutions. ${ }^{\mathrm{xv}}$ The board of directors of the BCRA was responsible for setting reserve requirements (Article 14b), establishing liquidity and credit worthiness ratios for banks (Article 14d) and revoking licenses of financial institutions when appropriate (Article 14h). A number of important regulations passed by the BCRA in 2001 contributed to the financial crisis. See the text

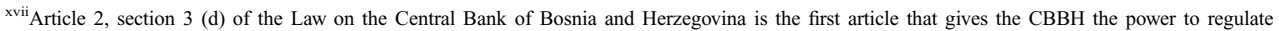
commercial banks. The CBBH also holds deposits for reserve requirements and coordinates the agencies responsible for bank licensing and supervision.

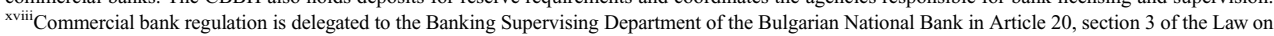
the Bulgarian National Bank.

${ }^{x i x}$ Article 2, section 5 of the Law on the Central Bank of the Republic of Estonia says, "Eesti Pank supervises all credit institutions within the Republic of Estonia. Eesti Pank monitors their activities as regards to conformity with laws, compulsory prudential ratios and regulations, and, within its jurisdiction, takes measures necessary to ensure strict adherence to laws, norms and regulation." Articles 14 and 17-24 articulate the latitude given to Eesti Pank in its bank regulations.

${ }_{\mathrm{xx}}$ The regulatory activies of the HKMA were brought under the same roof as the currency board in 1993. More generally, the Exchange Fund Ordinance was amended in 1992 to read: "In addition to using the Fund for its primary purpose, the Financial Secretary may, with a view to maintaining Hong Kong as an international financial centre, use the Fund as he thinks fit to maintain the stability and the integrity of the monetary and financial systems of Hong Kong." (Section 3 (1a))

${ }^{\mathrm{xxi}}$ Article 11, section 1 (2) of the Law on the Bank of Lithuania gives the board the power to set reserve requirements for commercial banks in Lithuania. xxii Article 20 of the BCRA's charter allowed the BCRA to hold $1 / 3$ of its assets (later 10 percent) in Argentine government bonds, and these holdings were not to increase by more than 10 percent in any calendar year. This law was broken in 2001 when government bond holdings increased by $\$ 3.5$ billion.

${ }^{x x i i i}$ Article 29, section 2 (1) of the Law on the Bank of Lithuania allows the Bank of Lithuania to buy government debt instruments in the secondary market.

${ }_{\text {xxiv }}$ The BCRA's charter set a floor of 2/3 (later 90 percent) of assets denominated in US dollars which cannot be issued by the Republic of Argentina. More specifically, those assets must be gold or claims on non-residents.

${ }_{\mathrm{xxv}}$ Article 27 (c) of the Law on the Central Bank of Bosnia and Herzegovina allows the Governing Board to set aside additional reserves beyond 110 percent coverage for specific purposes by unanimous decision. Article 31, section 1 indicates, "The Central Bank shall be abligated to ensure that the amount of its monetary liabilities shall at no time exceed the equivalent (in terms of the currency of Bosnia and Herzegovina) of its net foreign exchange reserves." Article 34 , section 2 allows the CBBH to hold up to 50 percent of its foreign exchange reserves in currencies other than the deutsche mark (euro).

${ }^{x x v i}$ Article 28, section 2 (2) of the Law on the Bulgarian National Bank sets a floor of 100 percent foreign reserve coverage, but no ceiling exists.

${ }_{x x v i i}$ There is nothing in the Law on the Central Bank of the Republic of Estonia that requires 100 percent foreign reserve backing of the currency or a fixed exchange rate. Clause 1 of the Law of the Republic of Estonia on the Security for Estonian Kroon states that cash in circulation, currency in current account and in accounts of a fixed date is fully backed by gold and convertible foreign reserves, thereby setting 100 percent foreign reserve coverage floor on what appears to be M1. Clause 4 states that currency in circulation may not be increased by Eesti Pank except by a corresponding increase in gold and foreign reserves.

${ }^{x x v i i i}$ Article 111 of the Hong Kong's Basic Law states that the issue of Hong Kong currency must be backed by a 100 percent reserve fund. Therefore, a floor, but no ceiling, exists on foreign reserve cover.

${ }^{x x i x}$ There is nothing in the Law on the Bank of Lithuania that requires 100 percent foreign reserve backing of the currency or a fixed exchange rate. Article 2 of The Law on the Credibility of the Litas sets a 100 percent foreign reserve coverage floor. 
another. These conflicts can potentially give rise to balance of payments crises which so often occur with so-called pegged exchange-rate regimes. (Hanke, 1998a; Mundell, 1963)

Why do the laws governing the new monetary authorities deviate from orthodoxy? The reasons vary. Argentina had employed currency board-like arrangements before (della Paolera and Taylor, 2001), and that experience weighed heavily on the design of the Convertibility Law of 1991. The Argentines knew full well what orthodox currency boards entailed and they did not want to be bound by orthodox rules.

In Estonia, Lithuania, Bulgaria and Bosnia and Herzegovina, the final design of the new laws was determined, in large part, by representatives of the International Monetary Fund. Based on my first-hand observations, the responsible IMF representatives had, at best, a superficial understanding of currency boards. ${ }^{8}$ They displayed no knowledge of currency board history or laws, and, in some cases, were openly hostile to the currency board idea. In the end, the IMF representatives could not conceive of a monetary authority without discretionary powers. Unable, or unwilling, to think outside the central banking box, they drafted laws based on those that govern central banks. Only two modifications were made to standard central bank laws: the specification of a fixed exchange rate and a floor under the foreign reserve cover for monetary liabilities.

Robert Mundell's observations on the IMF's prejudices concerning fixed exchange-rate regimes are noteworthy and consistent with my experiences in the field:

The IMF staff has shown equal fervor in denouncing fixed exchange rates or currency areas. In short, the Fund proved itself to be - and still is - a supporter of the status quo and an enemy of international monetary reform, suppressing dissent and controversy among its staff whenever it threatened to undermine the monolithic image of the corporate credo.

(Mundell, 1994: 13)

Mundell has also spoken specifically about the IMF's attitudes toward currency boards:

I have been very disappointed in the way the IMF has treated currency board arrangements, by and large. I think they should have grasped onto it. After all, let's suppose that apart from the fact that the United States dollar would be at the center of this thing, you could imagine a world of currency boards, where all central banks operate like currency boards - not currency boards but currency board systems. After all, that's what the gold standard was - it was what people nowadays call a currency board system. That's what the adjustment mechanism was. It was automatic until countries decided in the 1930 s to go off on independent monetary policies; then they got off on the wrong track. ${ }^{9}$

(IMF, 2000)

Finally, in the case of Hong Kong, the authorities deviated from orthodoxy because they wanted the monetary authority to take on the features of a typical central bank. With what appeared to be a simple change in accounting procedures in July 1988, this became evident to the trained eye. (Culp and Hanke, 1993) It became more obvious in 1993, when the monetary authority changed its name to the Hong Kong Monetary Authority (HKMA) and introduced other reforms.

Since, as a matter of law, the new monetary arrangements are not orthodox currency boards, I have characterized them as either "central banks that mimic currency boards" (Hanke et al., 1993: 72-77) or "currency board-like systems." (Hanke, 1996; 1997) In addition, I have repeatedly warned that the laws governing these new monetary authorities are flawed and that their deviations from orthodoxy are invitations for abuse and a drift toward something more akin to a typical central bank. (Hanke and Schuler, 1991d)

\section{CURRENCY BOARD-LIKE SYSTEMS IN PRACTICE}

As a matter of law, the new currency board-like systems can engage in neutralization. However, the question remains: Do these new monetary systems neutralize? 


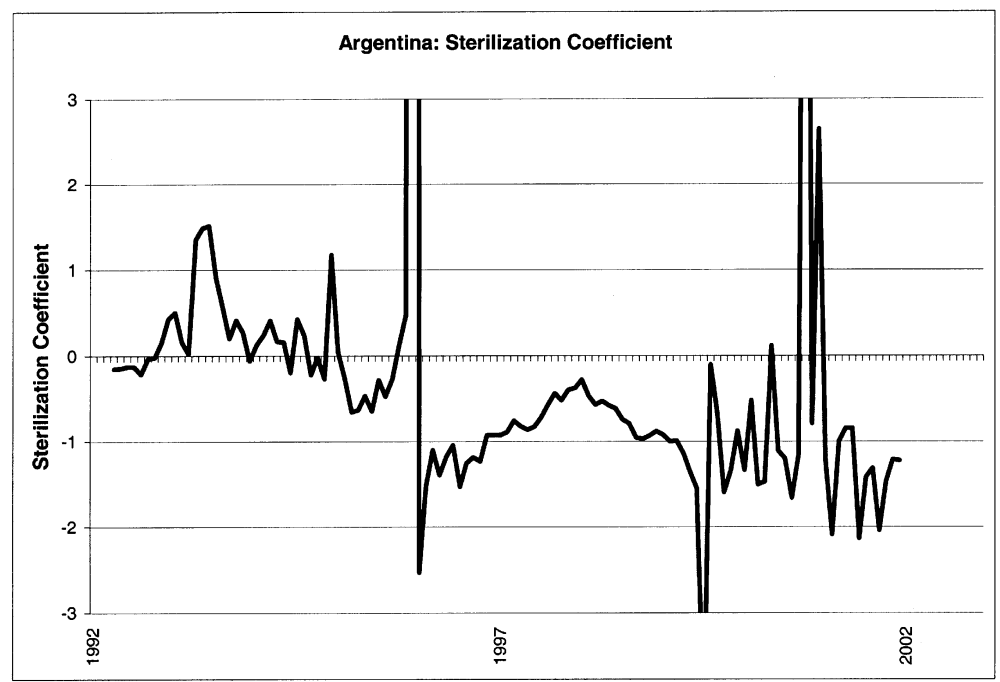

FIGURE 1 Argentina: sterilization coefficient.

To determine whether the new currency board-like systems have used neutralization to break the link between changes in their net foreign assets and base money, data from the IMF's International Financial Statistics and the balance sheets of the monetary authorities were utilized. Data for net domestic assets, net foreign assets and base ("reserve") money were obtained from these sources.

The following six figures speak for themselves and tell the neutralization story. The data are monthly, with changes computed on a year-over-year basis. With the exception of Hong Kong, the time series start one year after the inception of the new monetary arrangements and end on December 31, 2002. For Argentina, the time series terminates on December 31, 2001, the last full month in which the "convertibility" system operated.

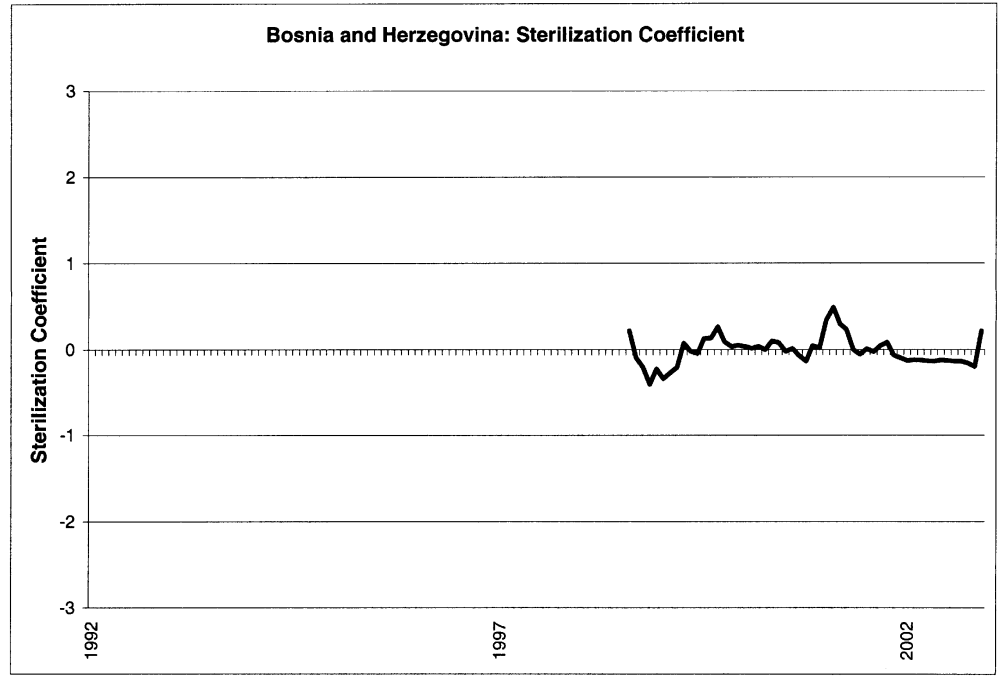

FIGURE 2 Bosnia and Herzegovina: sterilization coefficient. 
208

S. H. HANK

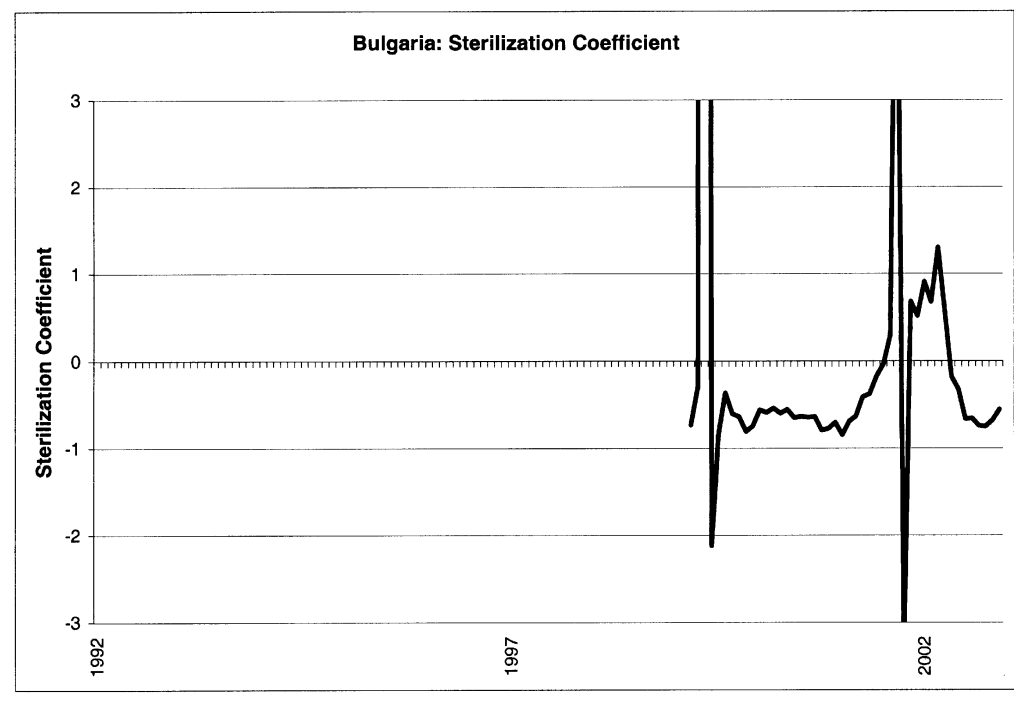

FIGURE 3 Bulgaria: sterilization coefficient.

The graphs show the ratio of the year-over-year change in net domestic assets to the yearover-year change in net foreign assets. This ratio is a sterilization coefficient. Changes in the monetary base are therefore decomposed into domestic and foreign components to calculate the coefficients. (Hanker, 2000a) If a monetary authority is operating as an orthodox currency board, changes in the monetary base only contain a foreign component and the sterilization coefficient is zero (or close to zero). Non-zero values signal that a monetary authority is deviating from currency board orthodoxy because the monetary base contains both foreign and domestic components. For example, full neutralization is observed when net domestic assets and net foreign assets move in opposite directions by equal amounts, yielding a steri-

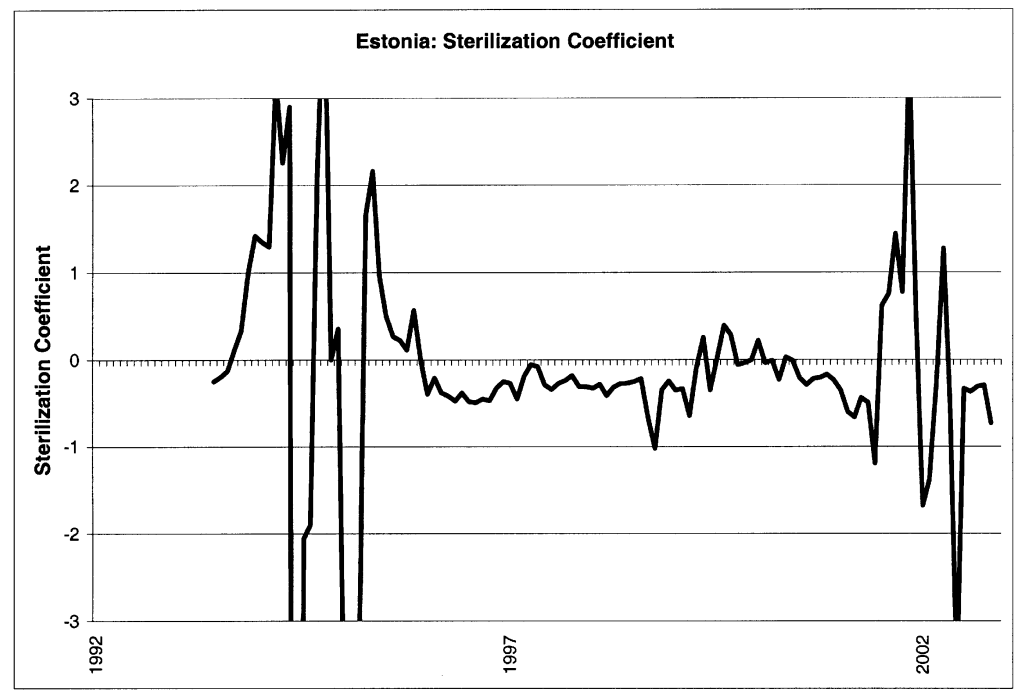

FIGURE 4 Estonia: sterilization coefficient. 


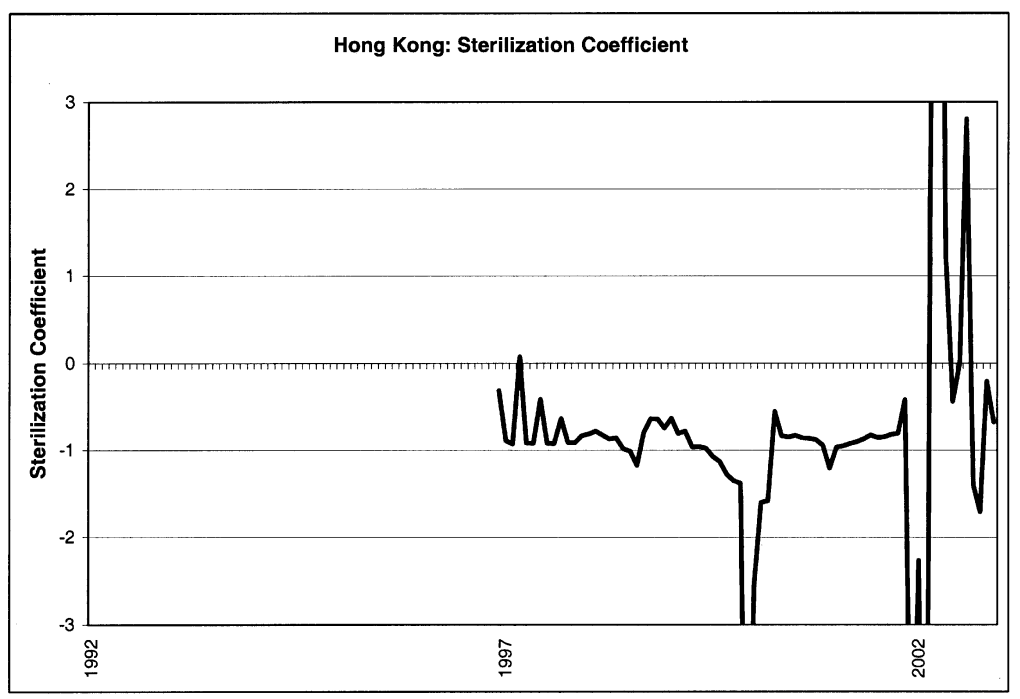

FIGURE 5 Hong Kong: sterilization coefficient.

lization coefficient of -1 . Values between 0 and -1 denote partial neutralization, and those less than -1 represent instances of more-than-complete neutralization. Positive sterilization coefficients apply to cases where net domestic assets and net foreign assets move in unison. ${ }^{10}$

With the exception of Bosnia and Herzegovina, considerable neutralization has occurred, indicating that the monetary authorities have used the discretionary powers granted to them by law. Several points regarding Bosnia and Herzegovina's orthodoxy are noteworthy. The Bosnian system was mandated by the Dayton/Paris Treaty (Article VII). The purpose was to establish an orthodox currency board, one that would tie the authorities' hands. In this case, the IMF followed the Treaty's script and drafted laws that comport reasonably well with currency board orthodoxy. A quasi-ceiling on the foreign reserve cover of the monetary base

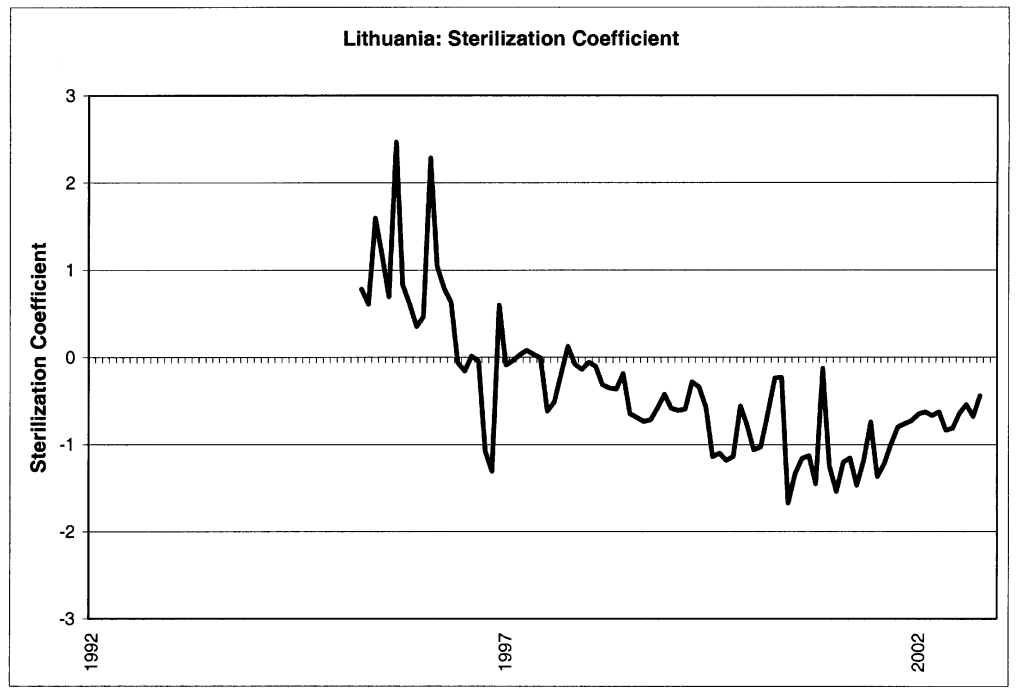

FIGURE 6 Lithuania: sterilization coefficient. 
TABLE II Sterlization Coefficients for Modern Currency Board-like Systems.

\begin{tabular}{llcr}
\hline Country & Time period & Sterilization coefficient & $P$-value \\
\hline Argentina & $1991(2)-2001(4)$ & -0.59 & 0.000 \\
Bosnia and Herzegovina & $1997(3)-2002(4)$ & -0.06 & 0.105 \\
Bulgaria & $1998(1)-2002(4)$ & -0.76 & 0.000 \\
Estonia & $1992(2)-2002(3)$ & -0.44 & 0.000 \\
Hong Kong & $1994(1)-2002(4)$ & -0.73 & 0.000 \\
Lithuania & $1994(2)-2002(3)$ & -0.73 & 0.000 \\
\hline
\end{tabular}

Note: The $P$-value represents the lowest significance level for which the sterilization coefficient is statistically significant. For example, if a 5 percent significance level is desired, any $P$-values of 0.05 or less indicate that the coefficient meets the desired level of significance.

was included (see Tab. I). ${ }^{11}$ In addition, the Dayton/Paris Treaty specified a feature that I had proposed in 1991 (Hanke and Schuler, 1991c): The Governor of the Central Bank may not be a citizen of Bosnia and Herzegovina, or any neighboring state. In consequence, the integrity of the laws and spirit of an orthodox currency board have been adhered to by Governor Peter Nicholl, a New Zealander.

In addition to the plots of the sterilization coefficients, a statistical analysis of neutralization was performed. Quarterly changes in net foreign assets and net domestic assets were normalized by dividing each by the previous quarter's stock of reserve money. The normalized net domestic assets variable was regressed against the normalized net foreign assets variable and a constant. (Fane, 2000: 141-42) The coefficients for the net foreign assets variable are reported in Table II. The negative signs accompanying the coefficients indicate that there was an inverse correlation between changes in net domestic and foreign assets. Accordingly, with the exception of Bosnia and Herzegovina, all the new systems engaged in significant neutralization of the monetary effects of changes in the balance of payments. The results, of course, tell the same story as the graphs. In addition, they allow for a ranking of the new systems, from the most orthodox (Bosnia and Herzegovina) to the least (Bulgaria).

As a matter of both law and practice, the new monetary systems - with the notable exception of Bosnia and Herzegovina - cannot rightfully be termed currency boards. Furthermore, the complaint repeated ad nauseam by critics of the new currency board-like systems - that the new systems lack discretionary powers - is, to use Frank Knight's favorite word, nonsense. (Stigler, 1988: 26-27)

That said, the new systems have produced relatively good macroeconomic results. Real GDP growth has been relatively strong, inflation relatively low and fiscal deficits relatively small. $^{12}$ (Hanke, 2002) However, these systems have not been trouble-free. Argentina's convertibility system proved to be crisis-prone and was finally abandoned in January 2002. And although Hong Kong's system weathered the Asian financial crisis of 1997-1998, it has been the subject of much controversy. Both systems merit further comment.

\section{ARGENTINA'S POLICY BLUNDERS}

Following Mexico's currency devaluation of December 1994, Argentina's convertibility system withstood a major speculative attack and in the process Argentina suffered a brief, but sharp, recession in 1995. I have analyzed that episode in detail elsewhere (Hanke, 1999). The lessons were clear: When the Banco Central de la República Argentina (BCRA) deviated from currency board orthodoxy - for example, when discounts and repos were used aggressively - they fueled speculation against the peso. When orthodoxy was embraced - for 
example, when the spread between buying and selling rates for US dollars was eliminated speculative pressures petered out.

The Argentines forgot nothing and learned nothing, however. When Fernando de la Rúa took office on December 10,1999, the economy was beginning to exhibit signs of a recovery after a mild recession. With the blessing of the IMF, his center-left Alliance government approved, in January 2000, what would be the first of three large tax increases designed to close a federal fiscal deficit of 2.5 percent of GDP. (Schuler, 2003) Stanley Fischer, the Acting Managing Director of the IMF, termed the first tax increase "an unfortunate necessity at the moment." (Fischer, 2000) "Unfortunate" turned out to be the operative word. In August 2000, I delivered a keynote address at the annual meeting of the Institute of Financial Executives in Bariloche, Argentina and concluded that the tax increase was impeding the recovery and severely undermining investor confidence. (Hanke, 2000b) Not surprisingly, the economy deteriorated rapidly, forcing the IMF to take the lead in a $\$ 40$ billion rescue package in December 2000. In March 2001, the Alliance broke up and Domingo Cavallo was appointed economy minister on March 20th. Ironically, Cavallo - the man who had put the convertibility system in place in 1991 - spent his 2001 tenure either exploiting loopholes in the Convertibility Law or dismantling the system.

Table III is a chronology summarizing Cavallo's hyperactivity. It is broken into three categories: (1) the exploitation of legal opportunities (and extra-legal actions) that directly affected the Banco Central de la República Argentina (BCRA), (2) actions taken to dismantle convertibility, and (3) actions that compromised confidence and credibility. Each event in the first category is coded according to the general powers granted to the BCRA: (D) financing the government deficit; $(\mathrm{R})$ regulating the banking sector ${ }^{13}$; (L) engaging in lender of last resort activities; (E) holding excess foreign reserves; $(\mathrm{N})$ holding less than 100 percent reserves. $^{14}$

A cursory examination of Table III shows just how many machinations were required to destroy what was - with all its flaws - a robust system. It also shows how far convertibility strayed from currency board orthodoxy. By deviating from orthodoxy, rather than embracing it - a lesson Cavallo should have learned during the 1995 crisis - he created a financial and economic fiasco of the first order. His mistakes illustrate what can occur when the most elementary and well-established principles of economics are flouted.

That said, it is worth recounting Argentina's neutralization story to dispel the semantical confusion found in the currency board literature. Contrary to assertions made by such distinguished economists as Barry Eichengreen, Argentina, as a matter of both law and practice, never employed a "pure currency board." (Eichengreen, 2002: 112) In virtually every month of convertibility's existence, the BCRA neutralized changes in its foreign reserves, and in most months after 1994, it did so aggressively. In the post-1994 period, the net domestic asset position of the BCRA was over six times more volatile than that of Chile's central bank, which was operating under a floating exchange-rate regime. Argentina's mix of a hyperactive monetary policy and a pegged exchange rate proved deadly. (Hanke, 1998a; Mundell, 1963)

\section{HONG KONG: THE SEEN AND NOT SEEN}

Hong Kong was caught up in the maelstrom of the 1997-98 Asian crisis. The first wave of speculation against the HK dollar began on October 21, 1997, the day after Taiwan floated its dollar. Early on October 23, it became apparent that the aggregate clearing balance of the Hong Kong banking system would be in deficit by approximately $\$ 1$ billion at the end of the day. That amount would normally have been borrowed from the HKMA's Liquidity 
TABLE III Exploitation and Dismantling of the Convertibility Law in Argentina.

1. Exploitation of legal opportunities (and extra-legal actions)

- April 9, 2001 - Argentine banks allowed to hold short-term government bonds as liquidity requirements (BCRA Communication No. A 3251). (R)

- April 30, 2001 - Argentine banks allowed to make peso-denominated loans against foreign currency liabilities (BCRA Communication No. A 3262). (R)

- May 31, 2001 - Argentine banks allowed to apply alternative risk-assessment procedures to government debt (BCRA Communication No. A 3280). (R)

- June 1, 2001 - BCRA ends reverse repos, expanding the monetary base by $\$ 7.5$ billion for a total expansion of $\$ 8.1$ billion - a 63 percent increase - in one day. Foreign reserve coverage drops from $155 \%$ to $98 \%$. (L, E)

- June 15, 2001 - Argentine banks allowed to apply alternative risk-assessment procedures to companies included in the "Agreements to improve competitiveness and generate employment" (BCRA Communication No. A 3286). (R)

- July 20, 2001 - Argentine banks allowed to refrain from revaluing loss-making government securities (BCRA Communication No. A 3303). (R)

- July 25, 2001 - Foreign reserve coverage of the monetary base dips below 90 percent, the lower bound set by the BCRA charter. With the exception of one day, foreign reserve coverage remains below this level until BCRA's receipt of $\$ 4.6$ billion in new IMF credits. $(\mathrm{N})$

- July 27, 2001 - Argentine banks allowed to apply alternative risk-assessment procedures to public sector loans (BCRA Communication A 3307). (R)

- August 1, 2001 - The BCRA opens its discount window. Rediscounts and overdrafts increase from zero to nearly $\$ 4$ billion by year's end. (L)

- September 7, 2001 - The IMF augments its credit to Argentina, bringing foreign reserve coverage of the monetary base above the legal limit of 90 percent for the first time since July 30, 2001. (N)

- Late October 2001 - BCRA's holdings of government bonds begin to grow rapidly. Government bond holdings increase from $\$ 1.344$ billion on January 2 to $\$ 4.879$ billion at year's end. Violates Article 20 of the BCRA's charter. (D)

- November 5, 2001 - Argentine banks allowed to apply alterative risk-assessment procedures to LECOPS and Patacones, locally-issued quasi-monies (BCRA Communication A 3354). (R)

- November 30, 2001 - Foreign reserve coverage of the monetary base falls below 100 percent for the first time since receipt of IMF credits. $(\mathrm{N})$

- December 12, 2001 - Foreign reserve coverage of the monetary base falls below 90 percent, again in violation of the lower bound set in the BCRA charter. $(\mathrm{N})$

- December 28, 2001 - BCRA introduces an additional bank liquidity fund. (L)

2. Actions taken to dismantle convertibility

- June 12, 2001 - Dual exchange-rate regime introduced under which exports (excluding oil) take place with a devalued peso and all imports with a revalued peso. The amount of devaluation/revaluation is equal to one half of the spread between the dollar and euro exchange rates (Convenios para Mejorar la Competitividad y la Generacion de Empleo, Decree 761/2001).

- June 25, 2001 - Bill to link the peso to a basket of 50 percent dollars and 50 percent euros is enacted (Argentina Law 25.445 modifying Law 23.928, Decree 803/2001).

- December 1, 2001 - Domingo Cavallo announces a deposit freeze. Overnight interest rates average 689 percent. Payment of higher interest rates on peso deposits prohibited. Limits on withdrawals from bank accounts enacted (BCRA Communication A 3372).

- January 6, 2002 - President Eduardo Duhalde announces Emergency Decree which devalues the peso, establishing a dual exchange rate regime with certain transactions executed at a fixed exchange rate of 1.4 pesos/dollar and others at a floating exchange rate. Foreign exchange trading suspended; bank holiday declared (BCRA Communication A 3421).

- January 11, 2002 - Foreign exchange trading resumes and banks reopen. Asymmetric pesofication of bank loans and deposits (BCRA Communications A 3424, 3425).

- February 11, 2002 - Exchange rate unified; floating regime commences (BCRA Communication A 3473).

3. Actions which compromised confidence and credibility

- March 20 - Domingo Cavallo becomes Economy Minister. Thirty day peso risk premium climbs from $50 \mathrm{bp}$ to 1929 bp on March 23.

- April 17 - Domingo Cavallo introduces bill to link the peso to a 50-50 US dollar/euro basket. Bill passes June 25.

- April 25 - President de la Rúa replaces Pedro Pou with Roque Maccarone as governor of the BCRA. Maccarone is reputed to be willing to "loosen" convertibility. Peso risk premium hits $1775 \mathrm{bp}$.

- July 11-26 - Three major credit rating agencies cut Argentina's credit rating. Peso risk premium spikes at 8869 bp on July 17.

- November 1, 2001 - Cavallo announces his intention to swap the majority of Argentina's \$132 billion debt.

- November 30, 2001 - A forced debt swap with the banking sector on unfavorable terms converts liquid paper into illiquid loans to the government. 
Adjustment Facility (LAF) without difficulty. But the normal course of events was not allowed to unfold. At 10:00 AM, to fight speculation, the HKMA unexpectedly issued a circular warning that repeated borrowers from the LAF would face penal rates. The banks panicked, on the assumption that the LAF rates would be prohibitive - a de facto closure of the LAF window. A scramble for liquidity ensued, with the Hong Kong interbank interest rate (HIBOR) spiking at 280 percent (Miller, 1999). Later in the day, the HKMA clarified its position, indicating that the LAF window would remain open and that the rates would not be prohibitive. This released the banks from the unnecessary, surprise liquidity squeeze engineered by the HKMA.

Although the liquidity panic vanished, the collateral damage created by the HKMA's actions remained in the system for months. Indeed, the HIBOR remained above its interest-arbitrage parity level with LIBOR. ${ }^{15}$ Speculators believed that the HKMA would again act to "defend" the HK dollar. Accordingly, they could not resist the potential profits that would be generated if there were another run-up in interest rates. After all, a sharp increase in the HIBOR would result in profits for those who were short the HK dollar forward (as opposed to spot).

This episode demonstrates once again why the HKMA is not an orthodox currency board. If the HKMA were orthodox, the LAF would not exist, the HKMA would be on autopilot, and the HKMA would never engage in activities designed to fight speculation.

Largely as a result of the HKMA's missteps, all was not well. The speculators perceived a lack of commitment by Hong Kong to maintain the official HK-US dollar parity. Always innovative, the speculators launched a massive "double play" in early 1998. They simultaneously went short both the HK dollar forward and the Hang Seng stock price index futures (HSI). The HIBOR rose well above its LIBOR, interest-arbitrage parity level. In consequence, the "double play" handsomely rewarded speculators: The rise in HIBOR immediately rewarded short currency forwards and knocked down the HSI, benefiting the HSI shorts.

In August 1998, the HKMA responded by engaging in counter-speculation: It purchased both equities outright and HSI futures. During that month, the HKMA engaged in counterspeculation to the tune of HKD 118 billion. (Jao, 2001: 87)

The counter-speculation in the stock market gave short-sellers of equities and the HSI pause, but failed to convince the HK dollar shorts that the HK dollar peg would be maintained. To dispel confusion, the HKMA announced the implementation of Seven Technical Measures (Jao, 2001: 67). Two are noteworthy. The first allowed banks to borrow from the HKMA at non-punitive rates and clarified the terms under which borrowing would be acceptable. The second - the Convertibility Undertaking - proved to be critical. It broke the back of speculators who were short the HK dollar forward. Licensed banks with credit balances in their clearing accounts were allowed to convert US dollars at the HKMA at a rate of HKD 7.75 to 1 , slightly below the official parity of 7.8 to 1 , with assurances that the rate would eventually return to 7.8 to 1 . This amounted to what Merton Miller (1999) termed "a barely disguised version of a put option," one that made the Hong Kong peg much more credible.

There was a torrent of commentary and debate about the actions of the HKMA, particularly its counter-speculation in the stock market. Regardless of whether commentators were pro or con, most believed that these actions amounted to a gross violation of currency board rules. Is this assertion correct?

If the HKMA's 1998 balance sheet had been disaggregated - with a separate presentation of the currency board's accounts, as has been the case since December 1998 (see Table IV) - it would be relatively easy to arrive at an answer to the question posed. However, at the time of the counter-speculation, the HKMA only made a quarterly, consolidated balance sheet public. A separate balance sheet for the currency board could not be seen. To determine whether the currency board of the HKMA was involved in the counter-speculation 
episode requires, therefore, some detective work and the piecing together of circumstantial evidence.

The Hong Kong government has for some time deposited surpluses with the HKMA, for which the government earned market interest rates. As these surpluses accumulated, the government looked to the HKMA for more competitive returns on its deposited funds. In consequence, the HKMA began actively managing this 'fiscal reserve' in April 1998 as part of the Exchange Fund's official assets (see Table IV). The official Exchange Fund assets are managed as a mixed HK- and US-dollar-denominated Investment Portfolio. This portfolio is separate from currency board assets. The HKMA organizes its other assets into a US dollardenominated Backing Portfolio. This portfolio backs the currency board's monetary liabilities (Hong Kong Monetary Authority, 1998: 76-77). During the time period under examination, these separate accounts could not be seen because the HKMA presented a consolidated balance sheet.

The available evidence suggests, however, that the HKMA purchased equities and HSI futures, which are denominated in HK dollars, by using the fiscal reserve, not the currency board assets. ${ }^{16}$ The intervention, therefore, represented nothing more than counter-speculation by what amounts to the government's own hedge fund.

So, just what is the available evidence? The first piece concerns the monetary base. If the currency board had been responsible for the purchase of HKD 118 billion in equities and HSI futures, base money would probably have exploded. However, base money actually contracted by 3 percent in the 3 rd quarter of 1998 compared to the 2 nd quarter. But this piece of evidence is not conclusive. After all, the purchase of equities and HSI futures could have represented nothing more than an almost complete offset of ostensibly huge external drains from the Hong Kong system. The behavior of base money, therefore, remains inconclusive.

To be more certain about the currency board's non-involvement in counter-speculation, the change in the monetary base must be decomposed into its foreign and domestic components.

TABLE IV Stylized Balance Sheet of the Hong Kong Monetary Authority.

\begin{tabular}{|c|c|}
\hline \multicolumn{2}{|c|}{ Exchange fund } \\
\hline Assets & Liabilities \\
\hline Foreign reserves (including fiscal reserve) & $\begin{array}{l}\text { Placements by Banks and other } \\
\text { financial institutions } \\
\text { Placements by Hong Kong statutory } \\
\text { bodies }\end{array}$ \\
\hline $\begin{array}{l}\text { Domestic assets (including Discount } \\
\text { Window lending }{ }^{1} \text { ) }\end{array}$ & $\begin{array}{l}\text { Placements by other Hong Kong } \\
\text { government funds government funds } \\
\text { Other liabilities } \\
\text { Net Worth }\end{array}$ \\
\hline $\begin{array}{l}\text { Backing assets } \\
\text { USD Investments } \\
\text { Interest Receivable } \\
\text { Other Receivables (net) }\end{array}$ & $\begin{array}{l}\text { Account } \\
\text { Monetary base } \\
\text { Certificates of Indebtedness } \\
\text { Exchange Fund Bills } \\
\text { Exchange Fund Notes } \\
\text { Coins in Circulation } \\
\text { Balance of the Banking System } \\
\text { Interest Payable } \\
\text { Other Payables (net) }\end{array}$ \\
\hline & Net Worth \\
\hline
\end{tabular}

\footnotetext{
${ }^{1}$ The Liquidity Adjustment Facility was renamed the Discount Window as part of the "Seven Technical Measures" of September 5, 1998.
} 
If the currency board had purchased the equities and HSI futures, the domestic component of the base would have increased by HKD 118 billion. And for a 3 percent contraction in base money to result, the foreign component of base money would have had to move in the opposite direction by an amount slightly greater than HKD 118 billion. Since that amount represented roughly 50 percent of base money, such a huge external drain would have been improbable, although not impossible.

If there had been huge external drains in a sophisticated, integrated financial system like Hong Kong's, they would have been accompanied by internal drains from the banking system. This did not occur. Indeed, during the 3rd quarter of 1998, both foreign currency and HK dollar deposits increased by 6.82 and 5.53 percent, respectively. (Jao, 2001: 74) Moreover, foreign currency deposits increased in both August and September 1998. All this suggests that external drains during the counter-speculation episode were, at most, minimal.

Although the Hong Kong currency board's deviations from orthodoxy contributed to Hong Kong's problems during the Asian crisis, strong circumstantial evidence supports the view that the currency board - contrary to most of the received wisdom - was not involved in the stock market counter-speculation. Rather, it appears that the intervention was funded by the fiscal reserve - the government's hedge fund - at the HKMA. The new unbundled HKMA accounts, which were available in November 1999, also lend credence to this interpretation. When the first portion of the HKMA's stock portfolio was liquidated in November 1999, the proceeds were credited back to the fiscal reserve. (Jao, 2001: 71) If nothing else, the diagnosis of Hong Kong's travails during the Asian crises demonstrates the importance of Sir John Hicks' dictum: There is nothing more important than a balance sheet. (Klamer, 1989)

\section{INDONESIA: THE GREAT GAME AND DECEPTIONS}

Indonesia, like Hong Kong, was caught up in the maelstrom of the Asian crisis. On August 14, 1997, shortly after the Thai baht collapsed on July 2, Indonesia floated the rupiah. Contrary to the expectations of the IMF (Fischer, 1997), the rupiah did not float on a sea of tranquility. It plunged from 2700 rupiahs per US dollar at the time of the float to lows of nearly 16,000 rupiahs per US dollar in 1998.

By late January 1998, President Suharto realized that the IMF medicine was not working and sought a second opinion. In February, I was invited to offer that opinion and began to operate as Suharto's Special Counselor. I concluded that the IMF's program had, as P. G. Wodehouse's character Ukridge said, "about as much chance as a one-armed blind man in a dark room trying to shove a pound of butter into a wild cat's left ear with a red-hot needle." (Wodehouse, 1980: 95) As an antidote, I proposed an orthodox currency board, and on the day that news hit the street the rupiah soared by 28 percent against the US dollar. This infuriated the U.S. government and the IMF. ${ }^{17}$

A withering and ruthless attack on me and the currency board idea ensued. I was transformed into a "dukun [traditional healer]" (McDermott et al., 1998), the "Rupiah Rasputin" (Krugman, 1998), and "Dr. Frankenstein" (Hirsh, 1998). This, of course, only proved the staying power of a tradition in primitive societies: "For though a man gains prestige by his productive capacities, if he outdoes his fellows too much, they will suspect him of witchcraft." (Gluckman, 1965: 88)

Not surprisingly, Suharto was told in no uncertain terms - by both the President of the United States, Bill Clinton, and Michel Camdessus, the Managing Director of the IMF - that he would have to drop the currency board idea or forego $\$ 43$ billion in foreign assistance. ${ }^{18}$ (Blustein, 1998; Camdessus, 1998a) 
Economists jumped on the bandwagon, too. Every half-truth and non-truth imaginable was trotted out in support of dumping the currency board idea. It was usually mixed with a good dose of ad hominem carping. For example, Charles Wyplosz piously wrote:

A US economist, Steve Hanke, managed to win the trust of President Suharto and to convince him to adopt a
currency board, against the IMF's advice. Within a few days, a large number of influential economists publicly
criticized Hanke, both his views and his standing in the profession. While it may have looked like a witch-hunt, it
was important that potentially dangerous advice be exposed as outside the mainstream. (Wyplosz, 1998: 29 fn. 9)

Apparently unaware that influential economists supported the currency board proposal including Gary Becker, Rudiger Dornbusch, Milton Friedman, Merton Miller, Robert Mundell, and Sir Alan Walters (Far Eastern Economic Review, 1998a,b,c; Nasar, 1998; Ortiz, 1999; Tyson, 1999; Walters, 1998) - Wyplosz clearly over-played his hand. ${ }^{19}$ But, never mind, the currency board idea was engulfed in an international feeding frenzy. And with that, the currency board idea was suddenly, if not ironically, reborn.

Why all the fuss over a currency board for Indonesia? Merton Miller understood the great game immediately. (Hanke, 2000d) This is what he had to say for the record: " 'There was a feeling Suharto was just another Ferdinand Marcos and we had to get rid of him.' Treasury's objection to the currency board was 'not that it wouldn't work but that it would, and if it worked, they would be stuck with Suharto.'” 20 (Tyson, 1999) Much the same argument was articulated by Australia's former Prime Minister Paul Keating: "The United States Treasury quite deliberately used the economic collapse as a means of bringing about the ouster of President Suharto." (Agence France Presse, 1999) Former U.S. Secretary of State Lawrence Eagleberger weighed in with a similar diagnosis, too: "We were fairly clever in that we supported the IMF as it overthrew [Suharto]. Whether that was a wise way to proceed is another question. I'm not saying Mr. Suharto should have stayed, but I kind of wish he had left on terms other than because the IMF pushed him out." (Agence France Presse, 1998) Even Michel Camdessus could not find fault with these assessments. On the occasion of his retirement, he proudly proclaimed: "We created the conditions that obliged President Suharto to leave his job." (Sanger, 1999)

To implement the political regime change in Indonesia, ${ }^{21}$ two deceptions were necessary. The first involved the IMF's public position of open hostility to currency boards. This deception was required to convince Suharto that he was acting heretically, and if he continued, it would be costly. The IMF's hostility required a quick about-face: Less than a year before the Indonesian uproar, Bulgaria had installed a currency board on July 1, 1997 with the enthusiastic endorsement of the IMF, and Bosnia and Herzegovina had followed suit under the mandate of an international treaty on August 11, 1997.

Shortly after Suharto departed, the IMF's currency board deception became transparent. On August 28, 1998, Michel Camdessus announced that the IMF would give Russia the green light if it chose to adopt a currency board. (Camdessus, 1998b) This was followed on January 16, 1999 with a little-known meeting in Camdessus' office at the IMF headquarters in Washington, D.C. The assembled included IMF top brass, Brazil's Finance Minister Pedro Malan and Francisco Lopes, the central bank's Director of Monetary Policy. "The substantive discussions started off with an aggressive proposal by Camdessus: Brazil, he said, ought to adopt a currency board." (Blustein, 2001: 360)

The second deception involved the widely-circulated story that I had proposed to set the rupiah's exchange rate at an overvalued level, so that Suharto and his cronies could loot the central bank's reserves. This take-the-money-and-run scenario was the linchpin of the Clinton administration's campaign against Suharto. It was intended to "confirm" Suharto's devious intentions and rally international political support for Suharto's ouster. ${ }^{22}$

The overvaluation story was enshrined by the Wall Street Journal. I was reported to have authored a report recommending an exchange rate of 5500 rupiahs to the US dollar. 
(McDermott et al., 1998) This was news to me. At the time, I had not authored any reports about Indonesia, nor had I proposed an exchange rate for the rupiah.

I immediately attempted to have this fabrication corrected. It was difficult, slow, and ultimately unsatisfactory. Although the Wall Street Journal reluctantly published a tiny, halfbaked correction in which it stated that I “... wasn't the author of a working paper outlining the benefits of a currency board in Indonesia," (Wall Street Journal, 1998) the damage had been done. ${ }^{23}$ The Journal's original fabrication was echoed in virtually every major magazine and newspaper in the world, and it continues to reverberate to this day, even in so-called scholarly books and journals.

Setting the record straight has been complicated enormously by the official spinners at the IMF. Indeed, they have been busy as little bees rewriting monetary history to cover up the IMF's mistakes. And Indonesia represents one of its biggest blunders. To this end, the IMF issued a 139-page working paper "Indonesia: Anatomy of a Banking Crisis: Two Years of Living Dangerously 1997-99." (Enoch et al., 2001) The authors include a largely fictive three-page account of the currency board episode. They assert, among other things, that I counseled President Suharto to set the rupiah-dollar exchange rate at $5000 .^{24}$ This pseudoscholarly account, which includes 115 footnotes, fails to document that assertion because it cannot be documented. And, speaking of documentation, the official IMF version of events fails to footnote any of my published works or interviews based on my Indonesian experience. Among other things, the authors overlooked a question and answer interview in which I was asked specifically about my exchange-rate recommendations, and responded by saying:

I can't give you the exact number that I thought would be realistic two weeks ago when I gave him (Suharto) my expert's report. It's been reported that I have recommended 5000 and that I have also recommended 5500 . Neither number is in my report. I did tell the president that the longer he waits, the weaker will be the realistic level at which you actually can set the exchange rate under a currency board regime. I think the best thing to do is announce you are putting in a currency board, let the currency float for 30 days, and then lock in to the exchange rate. That's exactly what we did in Bulgaria in 1997. It worked very well, and I think that's probably what they should do in Indonesia. (Broening, 1998)

In making its case against a currency board for Indonesia, the IMF also resorted to dogmatic arguments, indicating that it was either unable or unwilling to evaluate evidence. For example, Michel Camdessus asserted, in a letter to President Suharto, that “... for the introduction of a currency board to be successful, a number of preconditions need to be satisfied." (Camdessus, 1998a) He went on to assert that "You will certainly agree with me that these conditions are not satisfied at this time", and consequently the introduction of a currency board would risk "...extremely high interest rates... which would be very damaging for the economy." (Camdessus, 1998a)

Camdessus' assertions encapsulate a dogma propagated by the so-called Washington consensus. The President's Council of Economic Advisors spelled out the preconditions in 1999: "A currency board is unlikely to be successful without the solid fundamentals of adequate reserves, fiscal discipline and a strong and well-managed financial system, in addition to the rule of law". (Council of Economic Advisors, 1999: 289) Moreover, these precepts have been intoned by officials from the Federal Reserve System (Dow Jones, 1999) and the IMF (Rolnick, 2002: 29-30), and are contained in publications of the World Bank (World Bank, 1999: 132) and the Organization for Economic Co-Operation and Development. (OECD, 1997: 88-90)

Like any dogma, the precepts of the Washington consensus are assumed to be true and need not be subjected to empirical testing. This is nonsense. Successful currency boards have been introduced in many countries in which the alleged preconditions were not satisfied, including all the currency board-like systems introduced in the 1990s. In heaping praise on the performance of these new systems, the IMF's own reports document that inflation and 
interest rates fell dramatically, real growth rates switched from negative to positive, fiscal consolidation ensued and banking systems strengthened after the introduction of currency board-like systems. (Hanke, 2002)

The Washington consensus clings to its dogmatic arguments to obstruct the introduction of currency boards. After all, the preconditions can only be met by a relatively small group of countries. But if the preconditions are satisfied, why even consider a currency board?

My meetings in Jakarta with Michel Camdessus' special advisor, Prabhakar Narvekar, and the IMF's staff made clear that the IMF had likewise failed to understand objective, marketbased evidence. This evidence, on which I had laid great stress, suggested that an Indonesian currency board would be viable.

During the period in which the markets perceived that President Suharto would adopt a currency board, the rupiah strengthened dramatically against the US dollar in the spot market. More importantly, the one-year forward rupiah (the most liquid forward contract) moved in lock-step with the spot rupiah quotes. In consequence, the implied one-year forward interest rates contracted dramatically, indicating that lower interest rates were required to induce speculators to hold long rupiah forwards. The rupiah's one-day volatility, measured on a thirty-day rolling average, fell by about 50 percentage points during this period as well.

I argued that these objective market data indicated that market participants judged the currency board proposal credible and that a board would be viable for at least a year. Moreover, I noted that the markets did not buy the convoluted story about Suharto's intention to loot the Bank of Indonesia's foreign reserves. After all, if the markets believed that Washington concoction, the implied one-year interest rates would have been soaring, not collapsing.

To my surprise, the IMF team in Jakarta gave no indication that they were aware of the existence of a rupiah forward market. However, even after I presented the data and explained their implications, my arguments and evidence fell on deaf IMF ears. This left me, well, dumbfounded, particularly since the staff of the Bank of Indonesia understood exactly how the markets talked and what they were saying.

\section{REFLECTIONS}

As I reflect on the dollarization/currency board debate, I am left with an image of economists as Jean Henri Fabre's processional caterpillars. The great French naturalist made a classic study of these blind and unthinking critters as they wove their way through the grass in long chains, each following the one in front of it. Fabre managed to turn the chain and set all the followers in a circle. The rhythmic march had no end. For days they circled until starvation set in. The lesson is clear: The only way to avoid the caterpillars' fate is to carefully consider 'eccentric' economic arguments and weigh them against the evidence.

\section{Acknowledgements}

The author thanks Robert A. Mundell and Kurt Schuler for their comments and Matt Sekerke for his superb assistance. He also acknowledges Liliane Hanke's invaluable insights and wise counsel, particularly during their currency reform sojourns in Buenos Aires, Podgorica, Sarajevo, Sofia, Tallinn, Vilnius and other memorable locales. 


\section{References}

Agence France Presse (1998) US should be more tolerant toward Indonesia: Japanese Economist, 20 June. Agence France Presse (1999) Former Aussie PM says US used Asia crisis to oust Suharto, 11 November.

Bauer, P. T. (1976) Dissent on Development (Rev. ed.) Cambridge: Harvard University Press.

Beck, S. S. (1998) No vendetta, Asian Wall Street Journal, 20-21 February.

Blustein, P. (1998) Currency dispute threatens Indonesia's bailout: Clinton backs IMF in pressing Suharto not to change country's monetary system, Washington Post, 14 February, A1.

Blustein, P. (2001) The Chastening. New York: Public Affairs.

Broening, S. (1998) Voice of Suharto's guru: Q\&A/Steve Hanke, International Herald Tribune, 20 March, 15.

Camdessus, M. (1998a) A Letter to President Suharto, 11 February.

Camdessus, M. (1998b) Press Conference of IMF Managing Director Michel Camdessus. 28 August, http://www.imf.org/external/np/tr/1998/tr980828.htm.

Coase, R. H. (1994) Essays on Economics and Economists. Chicago: University of Chicago Press.

Coats, W. (1999) The central bank of Bosnia and Herzegovina: Its history and its issues, In: Blejer, M. I. and Skreb, M. (Eds), Central Banking, Monetary Policies and the Implications for Transition Economies. Boston, Dordrecht and London: Kluwer Academic Publishers, pp. 367-399.

Council of Economic Advisors (1999) The Annual Report of the Council of Economic Advisors. Washington, DC: US Government Printing Office.

Culp, C. L. and Hanke, S. H. (1993) The Hong Kong linked rate mechanism: Monetary lessons for economic development, Johns Hopkins University Department of Economics Working Paper, June.

Culp, C. L., Hanke, S. H. and Miller, M. H. (1999) The case for an Indonesian currency board, Journal of Applied Corporate Finance, 11(4), 57-65.

della Paolera, G. and Taylor, A. M. (2001) Straining at the Anchor: The Argentine Currency Board and the Search for Macroeconomic Stability, 1880-1935. Chicago: University of Chicago Press.

Dornbusch, R. (2001) Fewer monies, better monies, American Economic Review, 91(2), 238-242.

Dow Jones (1999) Fed's Meyer: Dollarization Risky for Nations with Weak Banks, 12 October.

Eichengreen, B. (2002) Financial Crises and What to Do About Them. Oxford: Oxford University Press.

Enoch, C. et al. (2001) Indonesia: anatomy of a banking crisis-two years of living dangerously 1997-99, IMF Working Paper 01/52, May, Washington, DC: International Monetary Fund.

Faircloth, L. (1998) Senator Faircloth: IMF and Rubin should support Indonesian currency board. US Senate Press Release, 13 February.

Fane, G. (2000) Capital Mobility, Exchange Rates and Economic Crises. Cheltenham, UK: Edward Elgar.

Far Eastern Economic Review (1998a) Sayings of Chairman Milton, 26 March, 78.

Far Eastern Economic Review (1998b) Habibie's New Deal. 4 June: 82.

Far Eastern Economic Review (1998c) Monetary Mischief, 2 July, 70.

Fischer, S. (1997) IMF Welcomes Indonesia's Exchange Rate Action, 14 August, http://www.imf. org/external/np/sec/nb/1997/nb9718.htm.

Fischer, S. (2000) Press Conference by Stanley Fischer, IMF Acting Managing Director, April 13, http://www.imf.org/external/np/tr/2000/tr000413.htm.

Fischer, S. (2001) Transcript of Press Conference by Stanley Fischer, First Deputy Managing Director, 8 May, http://www.imf.org/external/np/tr/2001/tr010508.htm.

Fischer, S. (2002) Financial crises and reform of the international financial system, NBER Working Paper No. 9297. Cambridge, MA: NBER.

Gluckman, M. (1965) Politics, Law and Ritual in Tribal Society. Chicago: Aldine Publishing Company.

Greenwood, J. (1982) Hong Kong's financial crisis: History, analysis, prescription, Asian Monetary Monitor, 6(6), 2-69.

Greenwood, J. (1983a) How to rescue the HK\$: Three practical proposals, Asian Monetary Monitor, 7(5), 11-39.

Greenwood, J. (1983b) The stabilization of the Hong Kong dollar, Asian Monetary Monitor, 7(6), 9-37.

Hanke, S. H. (1996/1997) A field report from Sarajevo and Pale, Central Banking, VII(3), 36-40.

Hanke, S. H. (1998a) How to establish monetary stability in Asia, Cato Journal, 17(3), 295-301.

Hanke, S. H. (1998b) How I spent my spring vacation, The International Economy, July/August, 30-33.

Hanke, S. H. (1999) Some reflections on currency boards, In: Blejer, M. I. and Skreb, M. (Eds), Central Banking, Monetary Policies and the Implications for Transition Economies. Boston, Dordrecht and London: Kluwer Academic Publishers, pp. 341-366.

Hanke, S. H. (2000a) Some reflections on monetary institutions and exchange-rate regimes, Zagreb Journal of Economics, 4(5), 77-92.

Hanke, S. H. (2000b) The confidence question, Forbes, 18 September, 177.

Hanke, S. H. (2000c) Reforming the IMF: Lessons from Indonesia, Central Banking, XI(2), $38-44$.

Hanke, S. H. (2000d) Special memories of a great economist, Wall Street Journal, 21 June.

Hanke, S. H. (2002) Currency boards, Annals of the American Academy of Political and Social Science, 579, $87-105$.

Hanke, S. H., Jonung, L. and Schuler, K. (1992) Monetary Reform for a Free Estonia. Stockholm: SNS Forlag (Published in Estonian in 1992).

Hanke, S. H., Jonung, L. and Schuler. K. (1993) Russian Currency and Finance. London: Routledge. 
Hanke, S. H. and Schuler, K. (1991a) Banco Central o Caja de Conversion? Buenos Aires, Argentina: Fundacion Republica.

Hanke, S. H and Schuler, K. (1991b) Teeth for the Bulgarian Lev: A Currency Board Solution. Washington, DC: International Freedom Foundation (Expanded versions were published in Bulgarian in 1996 and 1997).

Hanke, S. H and Schuler, K. (1991c) Monetary Reform and the Development of a Yugoslav Market Economy. London: Center for Research Into Communist Economies (Published in Serbo-Croatian in 1991).

Hanke, S. H and Schuler, K. (1991d) Argentina should abolish its central bank, Wall Street Journal, 25 October, A13.

Hanke, S. H. and Schuler, K. (1994) Valiutu Taryba: Pasiulymai Lietuvai. Vilnius, Lithuania: Lietuvos Laisvosios Rinkos Institutas.

Hayek, F. A. (1932 [1999]) The fate of the gold standard, In: Kresge, S. (Ed.), Good Money, Part I: The New World. Volume 5 of the Collected Works of F. A. Hayek. Chicago: University of Chicago Press, pp. 153-168.

Hirsh, M. (1998) Economists on the fly, Newsweek, 23 February, 17.

Ho, C. (2002) A survey of the institutional and operational aspects of modern-day currency boards, BIS Working Paper No. 110. Basel: Bank for International Settlements.

Holbrooke, R. (1998) To End a War. New York: Random House.

Hong Kong Monetary Authority (1998) Annual Report 1998. Hong Kong: HKMA.

IMF (2000) One World, One Currency: Destination or Delusion? Transcript of an Economic Forum, 8 November, http://www.imf.org/external/np/tr/2000/tr001108.htm.

Jao, Y. C. (2001) The Asian Financial Crisis and the Ordeal of Hong Kong. Westport, Connecticut and London: Quorum.

Klamer, A. (1989) An accountant among economists: Conversations with Sir John Hicks, Journal of Economic Perspectives, 3(4), 167-180.

Krugman, P. (1998) Rupiah Rasputin, Fortune, 137(7), 13 April, 115.

Kurtz, H. (1998) Spin Cycle: Inside the Clinton Propaganda Machine. New York: The Free Press.

Machlup, F. (1967) Essays in Economic Semantics. New York: W. W. Norton.

Machlup, F. (1977) A History of Thought on Economic Integration. New York: Columbia University Press.

McDermott, D., Solomon, J. and Pura, (1998) Suharto Considers pegging rupiah to dollar, Wall Street Journal, 10 February.

Miller, M. (1999) The put that protected the peg, Asian Wall Street Journal, July 12, 10.

Mundell, R. A. (1963) Capital mobility and stabilization policy under fixed and flexible exchange rates, Canadian Journal of Economics and Political Science, 29, November, 475-485.

Mundell, R. (1994) Prospects for the International Monetary System, World Gold Council Research Study No. 8. Geneva, Switzerland: World Gold Council.

Mundell, R. (2000) The Euro and the stability of the international monetary system, In: Mundell, R. and Clesse, A. (Eds), The Euro as a Stabilizer in the International Economic System. Norwell, Massachusetts: Kluwer Academic Publishers, pp. 57-84.

Nasar, S. (1998) Summit in Moscow: Economic memo, New York Times, 2 September, A10.

Organization for Economic Co-Operation and Development (1997) OECD Economic Surveys: Turkey. Paris: OECD.

Ortiz, X. (1999) Supply-side hero: A talk with Nobel winner Robert Mundell, Washington Times, 22 October.

Rolnick, A. J. (2002) Interview with Anne O. Krueger, The Region, December, 24-31.

Sanger, D. E. (1999) Longtime I.M.F. Director resigns in midterm, New York Times, 10 November, C1.

Schuler, K. (1996) Should Developing Countries Have Central Banks?, Research Monograph No. 52. London: Institute of Economic Affairs.

Schuler, K. (1999) The importance of being orthodox, Unpublished manuscript. Available at http://www.dollarization.org.

Schuler, K. (2003) Argentina's Prolonged Economic Crisis. Washington, DC: Joint Economic Committee of the United States Congress.

Sharpe, W. (1995) William Sharpe, In: Breit, W. and Spencer, R. W. (Eds), Lives of the Laureates: Thirteen Nobel Economists (3rd ed). Cambridge: The MIT Press, pp. 203-226.

Stigler, G. (1975) The Citizen and the State. Chicago: University of Chicago Press.

Stigler, G. (1988) Memoirs of an Unregulated Economist. New York: Basic Books.

The Indonesian Observer (1998) Lies about Indonesia, 13 February.

Tyson, J. L. (1999) 'Dollar Diplomacy' rises again as foreign-policy tool. Christian Science Monitor, 10 February.

Wall Street Journal (1998) Corrections and amplifications, 19 February, A2.

Walters, A. A. (1998) Currency board could save Indonesian economy from ruin, The Scotsman, 23 February.

Walters, A. A. and Hanke, S. H. (1992) Currency boards, In: Newman, P., Milgate, M. and Eatwell, J. (Eds), The New Palgrave Dictionary of Money and Finance (Vol. 1). London: The Macmillan Press, Ltd., pp. 558-561.

Wodehouse, P. G. (1980) Ukridge. London: Barrie and Jenkins.

World Bank (1999) Global Economic Prospects and the Developing Countries 1998/99. Washington, DC: The World Bank.

World Trade Magazine. (1998) World trade's most influential people, June, 42-48. 
Wyplosz, C. (1998) The culture of economic policy advice: An international comparison with special emphasis on Europe. Paper presented at the Research Colloquium on The State and Development of the Transfer Process of Economic Knowledge, St. Gallen, Switzerland, June 17-19. http://heiwww.unige. ch/ wyplosz/stgallen.pdf.

Zarazaga, C. (1995) Can currency boards prevent devaluations and financial meltdowns?, The Southwest Economy (Federal Reserve Bank of Dallas), July/August, 6-9.

\section{ENDNOTES}

${ }^{1}$ Although I focus on currency boards, much of what I write holds for the "dollarization" and "euroization" literature, too. For an overview, see Walters and Hanke (1992). For presentations of the arguments and evidence that meet Alchian's criteria for correctness and relevance, see Dornbusch (2001) and Schuler (1996), respectively. And for a prognosis about the fate of "dollarization" and "euroization" that is the same as my own, see Stanley Fischer's: "I believe it will ultimately happen...." (Fischer, 2002: 43)

${ }^{2}$ As Fritz Machlup $(1967 ; 1977)$ made clear, this is nothing new.

${ }^{3}$ Coase (1994: 5) stressed that the devil resides in the institutional details, something most economists eschew. With regard to the diagnosis of currency board laws, Ho (2002) is a notable exception. And when it comes to the importance of conducting sharp pencil work on balance sheets, there is no better authority than Sir John Hicks (Klamer, 1989).

${ }^{4}$ Krugman (1998) is particularly noteworthy. Although I refrain from refuting all the falsehoods and mischaracterizations contained in Krugman's diatribe, I will mention one. Krugman reports that I was not involved in the establishment of Argentina's convertibility system in 1991. If he had bothered to ask me about my involvement or if he had any familiarity with the literature, Krugman would have discovered a book that Kurt Schuler and I authored (Hanke and Schuler, 1991a), and upon reading the book's preface, which was written by former Argentine congressman Jose Maria Ibarbia, Krugman would have learned about my involvement in the early debates about convertibility.

${ }^{5}$ With reference to the "gold standard", Friedrich von Hayek posed a similar question, and concluded that what most observers characterized as a gold standard was not such a system. Indeed, Hayek found that the system, as it operated, deviated from gold standard principles because economists and central bankers - wrong-headedly, in Hayek's view - had elevated the stabilization of domestic prices "into a virtually unassailable dogma". (Hayek, 1932 [1999]: 154) In consequence, the sterilization of gold inflows and the offsetting of outflows was widespread, negating the self-adjusting feature of gold standard rules.

${ }^{6}$ John Greenwood, the principal architect of Hong Kong's monetary reforms in 1983, also carefully specified the features required for a monetary institution to qualify as an orthodox currency board (Greenwood, 1982; 1983a,b).

${ }^{7}$ It is clear that most critics of these new systems have not studied the laws that govern them. If they had, the critics would have been forced to refrain from going on-and-on about the systems' lack of discretionary powers, particularly those associated with the lender of last resort function (for example, see Zarazaga, 1995).

${ }^{8}$ A notable exception was Warren Coats (1999).

${ }^{9}$ For a contrary opinion on the workings of the gold standard, see Hayek's views in footnote 5 above.

${ }^{10}$ Four graphs contain spikes which exceed the range of sterilization coefficients shown on the vertical axis. The reason for these spikes becomes obvious when one considers how the sterilization coefficients are computed. Changes in net foreign assets are the denominator of the sterilization coefficient and those for net domestic assets are the numerator. Consequently, very small relative changes in net foreign assets can potentially generate very large (absolute value) coefficients. For example, a year-over-year change in net foreign assets of $-\$ 10$ combined with a change in net domestic assets of $+\$ 200$ will result in a sterilization coefficient of -20 . In most cases, the extreme values in the graphs are generated by data like those in the example, and for the purposes at hand, should be considered insignificant.

${ }^{11}$ The Law on the Central Bank of Bosnia and Herzegovina places a ceiling of 110 percent on foreign reserve coverage of monetary liabilities. The Governing Board may set aside additional reserves beyond 110 percent for specific purposes by unanimous decision. Refer to Table I, note 25 for more information.

${ }^{12}$ Stanley Fischer confirmed this in a press conference announcing his retirement from the IMF. When asked what his proudest moment had been during his tenure at the IMF, Fischer said, among other things, "We were asked to design a monetary system for Bosnia-Herzegovina one weekend. The Fund of the staff [sic] started working on Saturday and by Monday they had it. The currency board that has operated so successfully in Bosnia-Herzegovina precisely as the staff of this institution suggested worked out and put in practice. [sic] There is Bulgaria, another country that was on the brink of hyperinflation, read disaster, that is operating well. I could go on and on." (Fischer, 2001)

${ }^{13}$ The importance of the regulatory changes in the development of Argentina's crisis may not be immediately obvious. Broadly speaking, changes in regulations during the crisis encouraged the banking sector to absorb a greater portion of the government's outstanding debt. Changes in risk assessment procedures allowed banks to acquire those risky assets without a corresponding increase in capital, per standard capital adequacy requirements. Other operations were allowed which encouraged excessive risk taking. For example, regulatory changes on July 20, 2002 permitted banks to hold loss-making positions in government bonds without marking them to market prices.

${ }^{14}$ During the early stages of the crisis in 2001, the BCRA's charter permitted holdings of US dollar-denominated Argentine government bonds up to 10 percent of monetary liabilities. The other 90 percent of assets backing 
monetary liabilities was to be comprised of pure foreign reserves, for a total of 100 percent backing.

${ }^{15}$ The official HK-US dollar parity of HK 7.8 to 1 is maintained in the Hong Kong system via the interest-rate arbitrage between the HIBOR and LIBOR.

${ }^{16}$ It is also important to note that the fiscal reserve is roughly three times as large as the assets backing the currency board's monetary liabilities. The huge stock market intervention represented about half of currency board assets, but only about one sixth of the fiscal reserve assets.

${ }^{17}$ If the idea of an Indonesian currency board was not bad enough, President Suharto's desire to obtain a second non-IMF opinion constituted an act of blasphemy. As Michel Camdessus (1998a) wrote to Suharto: "In this context I am concerned by the persistent reports about the imminent announcement of the introduction of a currency board in Indonesia. I am certain you would not adopt such a major step without a meaningful consultation with the IMF, as the letter of intent states that 'During the period of the proposed stand-by arrangement, Indonesia will consult with the Managing Director of the Fund on the adoption of any measure that may be appropriate at the initiative of either the Indonesian authorities or the Managing Director, in accordance with the Fund's policies on such consultations."'

${ }^{18}$ This episode created a heated debate and landed Bill Clinton, Michel Camdessus and the author on a list of the twenty-five most influential people in the world in 1998. (Faircloth, 1998; World Trade Magazine, 1998)

${ }^{19}$ Others failed to get their facts and arguments straight, too. Indeed, most employed an unoriginal standard formula, one that contained contradictory claims. On the one hand, I was depicted as an obscure economist who had played a minor, or no, role in the currency board reforms of the 1990s; on the other hand, I allegedly had an enormous and corrupting influence in the currency reform sphere. (Krugman, 1998)

${ }^{20}$ As much was confirmed to me at a luncheon at the Grand Hyatt Hotel in Hong Kong on March 27, 1998 by none other than Richard Holbrooke, the architect of the Dayton/Paris treaty that mandated a currency board for Bosnia and Herzegovina (Holbrooke, 1998: 256-58)

${ }^{21}$ Interestingly, one of the fathers of the regime change doctrine embraced by the current Bush administration is Paul Wolfowitz. He served as the U.S. Ambassador to Indonesia (1986-1989), a non-trivial fact. Another non-trivial fact concerns Bill Clinton's alleged campaign finance shenanigans and his close ties to James Riady, whose family owned Indonesia's Lippo Bank. (Kurtz, 1998: 52-55, 118, 178)

${ }^{22}$ To argue that an Indonesian currency board would have been Suharto's personal mechanism for capital flight is to confuse real assets with financial assets. The wealth of the Suharto family was mainly in the form of real assets like factories, power plants, airports, docks, and toll roads. Such assets, which were illiquid at the time, would still have remained in Indonesia no matter what the Suhartos did. After all, was Suharto going to roll up toll roads like rugs and cart them off to Switzerland?

${ }^{23}$ For an elaboration on the other fabrications contained in the Wall Street Journal article, see The Indonesian Observer (1998) and Beck (1998).

${ }^{24}$ The IMF staff apparently holds out the vain hope that assertions will miraculously be transformed into facts if they are contained in an IMF report. This exercise in creative historiography simply confirms my field observations in Jakarta: The staff was neither trustworthy nor competent. (Hanke, 1998b; 2000c) Had the staff read my works on currency boards and the fixing of an exchange rate, they would have discovered my advocacy of a temporary free float prior to fixing a currency board's exchange rate. These market-based prices should then be employed to fix a rate in the "range of recent market rates." (Hanke et al., 1993: 86) Moreover, "it is best to err on the side of an apparent slight real undervaluation..." (ibid). Not surprisingly, this was the approach I recommended in Indonesia. (Culp et al., 1999: 60) 